UNIO - EU Law Journal. Vol. 5, No. 1, January 2019, pp 40-53.

®2019 Centre of Studies in European Union Law

School of Law - University of Minho

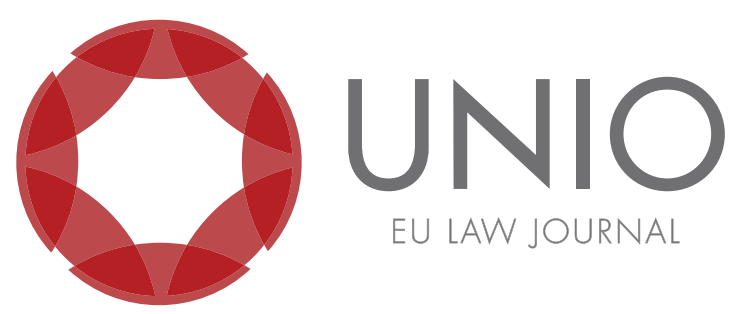

\title{
The regulation of collaborative economy in the European Union
}

\section{Nuno Cunha Rodrigues*}

ABSTRACT: The paper distinguishes between sharing economy and collaborative economy, focusing on the legal framework of collaborative platforms (such as Uber or Airbnb) according to EU law. Case-law from the Court of Justice of the European Union (CJEU) and the position of the European Commission are analyzed in this regard. It is concluded that there is no harmonization, within the European Union, of the legal regime applicable to certain collaborative platforms. As such, specific regulation of collaborative platforms has followed different paths within the Member States.

KEYWORDS: collaborative economy - sharing economy - competition law - Uber - Airbnb.

\footnotetext{
* Professor of the Law School of the University of Lisbon. Jean Monnet Chair holder.
} 


\section{The concept of collaborative economy}

One of the innovations brought by the economy of the $21^{\text {st }}$ century was the emergence of electronic platforms accessible through any computer or a simple mobile phone that enable the shared use of goods or services.

These platforms had a disruptive effect on several sectors of economic activity allowing, in many cases, the division of the cost of using a good and, as so, making it more accessible to consumers.

Sharing economy, typically, would be concerned with the business model called point-to-point (peer-to-peer - P2P), through which anyone can transact or share goods or services directly to another without intermediary. ${ }^{1}$

Still, it turns out that a large part of the existing electronic platforms act as a professional intermediary in the supply and demand of goods or services between two different people. As so, one can't speak of a point-to-point business model. ${ }^{2}$ In contrast, it's a business model that involves three distinct entities: the seller or service provider, the intermediary, and the buyer of the good or service. Many point out, therefore, that electronic platforms do not act passively but replicate a business to consumer business model (B2C) by which they seek to aggregate supply and demand in certain markets (running the platform as a market-maker in bilateral or multilateral markets). ${ }^{3}$ This model is present in platforms such as Uber (in the urban transport sector) or Airbnb (local accommodation).

The difference between $\mathrm{P} 2 \mathrm{P}$ and $\mathrm{B} 2 \mathrm{C}$ business models has motivated some conceptual confusion. Several refer to the first (P2P) as collaborative economy while the second (B2C) is referred to as sharing economy. ${ }^{4}$ Others also describe the latter as collaborative economy.

\footnotetext{
${ }^{1}$ Distinguishing professional sellers from occasional (peers) ones, see Liran Einav, Chiara Farronato and Jonathan Levin, "Peer-to-Peer Markets," Annual Review of Economics, vol. 8, issue 1 (2016): 622, https: / /web. stanford.edu/ leinav/pubs/AR2016.pdf. Also Zoe Cullen and Chiara Farronato, "Outsourcing Online Tasks: Matching Supply and Demand on Peer-to-Peer Internet Platforms”, Working Paper (February 2018), https://pdfs.semanticscholar.org/b50f/b4df2c1463973c6e3b738bf90db7b5f8ccSeepdf.

${ }^{2}$ See Giana M. Eckhardt and Fleura Bardhi, "The Sharing Economy Is not About Sharing at All", Harvard Business Review (January 2015), https://hbr.org/2015/01/the-sharing-economy-isnt-aboutsharing-at-all. As well observed by Margherita Colangelo and Mariateresa Maggiolino, "Uber and the challenges for antitrust law and regulation,” Media Laws - Rivista di diritto dei media, vol. 1 (2018): 177, http://www.medialaws.eu/wp-content/uploads/2018/02/Colangelo.pdf, "sharing is not an accurate description of the services that run on digital platforms like Uber".

${ }^{3}$ Analyzing from an economic perspective of the impact in competition of bilateral (two-sided platforms) or multilateral (multi-sided platforms), see Jean Tirole and Jean-Charles Rochet, "Platform competition in twosided markets," Journal of the European Economic Association, vol. 1, No. 4 (June 2003): 990-1029, https: / /www. rchss.sinica.edu.tw/cibs/pdf/RochetTirole3.pdf; David S. Evans and Richard Schmalensee, "The antitrust analysis of multi-sided platform businesses," Working Paper 18783 (February 2012), http:/ /www.nber.org/ papers/w18783; Cyril Ritter, "Antitrust in two-sided markets: looking at the US Supreme Court's Amex case from an EU perspective," Journal of European Competition law in Practice, lpy077 (2018), https:/ / academic. oup.com/jeclap/advance-article/doi/10.1093/jeclap/lpy077/5281284 and Dirk Auer and Nicolas Petit, Two-Sided Markets and the Challenge of Turning Economic Theory into Antitrust Policy, January 20, 2015, https:/ / ssrn.com/abstract $=2552337$.

${ }^{4}$ In this sense see Christoph Busch, "The sharing economy at the CJEU: does Airbnb pass the 'Uber test ??", EuCML, issue 4 (2018): 172-174; Roberta A. Kaplan, "Regulation and the Economy Shaping", NYLJ, vol. 252, No. 12 (2014); Christopher Koopman et al., "The Sharing Economy and Consumer Protection Regulation: The Case for Policy Change", The Journal of Business \& Entrepreneurship the Law, vol. 8, issue 2 (May, 2015), https://ssrn.com/abstract=2535345 and Alessio Di Amato, "Uber and the Sharing Economy," The Italian Law Journal, vol. 02, No. 01 (2016): 185.
} 
The definition of collaborative economics is therefore not consensual. ${ }^{5}$

However, one can say that there is a gradual convergence between the institutions of the European Union around the concept of collaborative economy, associated with several electronic platforms. ${ }^{6}$

We will therefore use the concept of collaborative economy and collaborative platforms to express the $\mathrm{B} 2 \mathrm{C}$ business model used, by which a third entity is responsible for ensuring the intermediation between supply and demand in a given relevant market.

The concept of collaborative economy (B2C) seems to be more rigorous, since, as we shall see, collaborative platforms exercise, in most cases, an economic activity that is not strictly confused with direct sharing of goods or services between two entities (P2P).

\section{The activity carried out by collaborative platforms}

\section{The position of the European Commission}

The assessment of the consequences of collaborative platforms has generated some controversy since it's needed to adequate them into the current legal framework. One has to know if platforms are service providers stricto sensu - submitted to the Services Directive ${ }^{7}$ - or providers of "information society services" - and, in this context, to the E-commerce Directive. ${ }^{8}$

The consequences of subsuming collaborative platforms to one or the other Directive are not negligible.

The implementation of the first - the E-commerce Directive - determines that, the so-called "internal market clause" provided for in Article 3, paragraph 2 of the Directive, which prevents Member States from restricting the free movement of information society services from another Member State, should be respected. ${ }^{9}$

In a different way, the regulation of the Services Directive to platforms not covered by the E-commerce Directive determines a subsequent and specific analysis of the services provided through the platform since, in some cases, they may be excluded from the subjective scope of the Services Directive as it does not apply to sectors such as transport, financial services, temporary work and health services. ${ }^{10}$

This is a problem that has been discussed in the past by the European

\footnotetext{
${ }^{5}$ Discussing the existence of a hat-concept for sharing and collaborative economy, see Daniela Selloni, Codesign for public-interest services (Switzerland: Springer, 2017), 15-20.

${ }^{6}$ See Communication from the Commission to the European Parliament, the Council, the European Economic and Social Committee and the Committee of the Regions a European Agenda for Collaborative Economy [COM (2016) 356 final], Brussels, 06 February 2016 and the European Parliament Resolution of 15 June 2017, on a European Agenda for Collaborative Economy (2017/2003 (INI)). The weight of the collaborative economy in the European Union is equivalent to $€ 26.5$ billion (about $0.17 \%$ of GDP in the EU in 2016) and employs around 394,000 people. These data can be found at http:/ / ec.europa.eu/growth/content/collaborative-economy-studies_enployment.

${ }^{7}$ Directive 2006/123 of the European Parliament and of the Council of 12 December 2006 on services in the internal market ("Services Directive").

${ }^{8}$ Directive 2000/31 of the European Parliament and of the Council of 8 June 2000 on certain legal aspects of information society services ("E-commerce Directive").

9 This means that a collaborative platform considered to provide "information society services" is covered by this Directive and can operate throughout the European Union.

${ }^{10}$ See Article 2 (2) of the Services Directive.
} 
Commission in the Communication issued in 2016 entitled "A European Agenda for Collaborative Economy". ${ }^{11}$

In that document, the Commission considered that the equalization of a collaborative platform to a provider of the service considered the preliminary inquiry about the level of control or influence exercised over the person that, at the end, performed the service:

This would require compliance with the following conditions:

a) Price. In this case, it should be the platform to set the final price to be paid by the user as beneficiary of the underlying service.

b) Ownership of key assets. The collaborative platform would own the key assets used to provide the underlying service.

c) Other essential contractual conditions. Thus, it would be for the platform to establish other terms and conditions, apart from price, that determine the contractual relationship between the underlying service provider and the user.

For the European Commission, the cumulative fulfillment of these three conditions would determine the qualification of the collaborative platform as the provider of the underlying service, in particular with a view to assure the application of the Services Directive.

If not, the platform would be qualified as an "information society service provider" and would therefore be submitted to the E-commerce Directive.

\section{The jurisprudence of the Court of Justice of the European Union (CJEU)}

Qualification of collaborative platforms was recently appreciated by the CJEU. In the Elite Taxi/Uber decision, ${ }^{12}$ the problem was whether the Uber collaborative platform was subject to the E-commerce Directive or, in a different way, to the Services Directive. ${ }^{13}$

In this case, the CJEU first considered that Uber could, in abstract, be regarded as an intermediary and, in that case, be described as provider of an "information society service". ${ }^{14}$ On the other hand, a non-collective urban transport service, such

\footnotetext{
${ }^{11}$ The Communication also sought to provide non-binding guidance on how EU legislation applies to business models of collaborative economy by examining five key issues relating to (1) market access requirements, (2) liability regime, (3) protection of users, (4) self-employed workers and workers in the collaborative economy, and (5) taxation.

${ }^{12}$ See Judgment Elite Taxi/Uber, 20 December 2017, case C-434/15, ECLI:US:C:2017:981. There are two other decisions of the CJEU relating to Uber. The first concerns Uber France, 10 April 2018, case C-320/16, ECLI:C:2018:221 - which raised the question whether certain provisions of national law applicable to services such as that proposed by Uber should have been notified as rules on services in aception of the provisions of EU law on the technical notice. A second reference for a preliminary ruling on that question was dismissed as it was considered inadmissible by order of 27 October 2016, Uber Belgium, case C-526/15, unpublished, EU:C:2016:830.

${ }^{13}$ As stated by Advocate General Maciej Szpunar in the Opinion of 11 May 2017 in case C-434/15 Elite Taxi, the object of the process is quite limited and concerns "(...) whether possible rules on how Uber operates are subject to the requirements of $E U$ law, in the first place those relating to the freedom to provide services, or whether they fall within the scope of the shared competence of the European Union and the Member States in the field of local transport, a competence which has not yet been exercised at EU level' (see paragraph 2).

${ }^{14}$ See Paragraph 35 of the Judgment and Article 1 (2) of Directive 98/34, to which Article 2 (a) of the E-commerce Directive refers. This intermediation service constitutes, as the definition stated in Directive 98/34 provides, "any service normally provided for remuneration, at a distance, by electronic means and at the individual request of a recipient of services".
} 
as a taxi service, should be classified as a "transport service". ${ }^{15}$

However, the CJEU noted that a service such as Uber is not limited to intermediation as it "(...) simultaneously offers urban transport services, which it renders accessible, in particular, through software tools such as the application at issue in the main proceedings and whose general operation it organises for the benefit of persons who wish to accept that offer in order to make an urban journey" (see paragraph 38).

The existence of the platform (application) Uber is, to the CJEU, essential to the activity so that without the application, "(...) those drivers would not be led to provide transport services and (ii) persons who wish to make an urban journey would not use the services provided by those drivers". ${ }^{16}$ The application can therefore be considered essential for the functioning of the market, being Uber, to be considered as a market-maker.

According to the CJEU, Uber exerts a decisive influence on the conditions of the provision of drivers, since, in particular, by applying at least the maximum price of the journey it charges the customer before delivering a part of it to the unprofessional driver of the vehicle and ensures a certain degree of control over the quality of the vehicles and their drivers' behavior, which may entail, when appropriate, their exclusion. ${ }^{17}$

The Court concluded that Uber forms an integral part of a global service whose principal element is transport. In other words, although a mixed service is involved, the main element in this is transport. Uber should therefore be classified as "service in the field of transport"18/19 and not an "information society service".

In so far as it qualifies as a "service in the field of transport", it is not covered by Article 56 TFEU on the freedom to provide services in general. But Article 58(1) TFEU, ${ }^{20}$ which concerns the principle of freedom to provide services, must be applied through the implementation of a common transport policy.

\footnotetext{
${ }^{15}$ See Paragraph 36 and Article 2, paragraph 2, point d) of Directive-Services, read in the light of recital 21 (see, to that effect, Trijber et Harmsen, 1 October 2015, case C-340/14 and C-341/14, EU:C:2015:641, paragraph 49).

${ }^{16}$ See paragraph 39.

${ }^{17}$ Indeed, as several authors observe, Uber provides the payment systems that drivers and consumers use; ensures the dynamic operation of prices; charges commissions for each service provided and guarantees and supervises the quality of the services provided by the drivers. See Colangelo and Maggiolino, Uber and the challenges for antitrust, 178. Commenting the Elite Taxi/Uber case, see Damien Geradin, "Online Intermediation Platforms and Free Trade Principles - Some Reflections on the Uber Preliminary Ruling Case”, SSRN Electronic Journal (April 2016), https://ssrn.com/abstract=2759379 and Margherita Colangelo and Mariateresa Maggiolino, "Uber in Europe: are there still judges in Luxembourg?,” CPI Antitrust Chronicle: Diving into online platforms, vol. 2 (Spring, 2018): 32-37, https:/ / www.competitionpolicyinternational.com/wp-content/uploads/2018/05/AC_May.pdf.

${ }^{18}$ See paragraph 40 and Article 2 (2) (d) of the Services Directive. The Court added in paragraph 41: "(...)That classification is indeed confirmed by the case-law of the Court, according to which the concept of 'services in the field of transport' includes not only transport services in themselves but also any service inherently linked to any physical act of moving persons or goods from one place to another by means of transport (see, to that effect, Judgment of 15 October 2015, Grupo Itevelesa and Others, C-168/14, EU:C:2015:685, paragraphs 45 and 46, and Opinion 2/15 (Free Trade Agreement with Singapore) of 16 May 2017, EU:C:2017:376, paragraph 61)".

${ }^{19}$ Thus, the E-commerce Directive, shall not apply to a brokerage service like Uber but is not subject to Services Directive, since, according to Article 2, paragraph 2, point (d) of that directive, such services are expressly excluded from the scope.

${ }^{20}$ See Paragraph 44 of the Judgment: specific provision under which "(..) freedom to provide services in the field of transport shall be governed by the provisions of the Title relating to transport' (see, to that effect, judgment of 22 December 2010, Yellow Cab Verkehrsbetrieb, C-338/09, EU:C:2010:814, paragraph 29 and the case-law cited)".
} 
According to the Court, knowing that non-collective urban transport services and services inextricably linked to it, such as Uber intermediary service, did not result in the adoption, by the European Parliament and the Council of the European Union, of common rules or other measures, on the basis of Article 91 (1) TFEU, it is up to the Member States to regulate the conditions for the provision of such services. $^{21}$

In summary, the CJEU applied to Uber a test which, from this point of view, came to be known as "Uber test", which aims to determine whether a given collaborative platform acts as a mere intermediary - consequently covered by the E-Commerce Directive - or as service provider - in this case covered by the Services Directive - in the light of which it will be necessary to examine whether the following conditions are fulfilled:

(i) The indispensability of the platform (application) for the provision of the service (market-maker);

(ii) The exercise, by the platform, of a decisive influence on the conditions of the provision of the service, namely, by fixing:

a. Price (for example the maximum price);

b. Control over the quality of the service provided;

c. Possibility of exclusion of service providers.

These criteria are similar, in some way, to those proposed by the European Commission in 2016, which included (i) price; (ii) ownership of the main assets and (iii) other essential contractual conditions.

They are, however, less demanding because, for the CJEU, for a platform to be indispensable and capable of exerting a decisive influence on the conditions of the provision of the service so that it is not only qualified as an intermediation service, it is not necessary to own the main assets as it arose from the communication, in 2016, of the European Commission.

The Uber test will surely be used in the future to be applied to other collaborative platforms such as Airbnb.

In that regard, in the Uber conclusions, Advocate General Maciej Szpunar seemed to qualify Airbnb as being part of the information society services. ${ }^{22}$

The decision-making practice of several competition authorities seems to go in the opposite direction. Several national competition authorities (e.g. in the UK, Germany, France and Sweden) considered recently in cases involving online travel agencies (such as Booking or Expedia) that they did not act as mere intermediaries, as they impose conditions essential for the definition of the price, in particular by

\footnotetext{
${ }^{21}$ See Paragraphs 46 and 47 of the Judgment.

${ }^{22}$ In his Opinion delivered on Elite Taxi v Uber, 11 May 2017, case C-434/15, ECLI:EU:C:2017:364, the Advocate General applied the Uber test to Airbnb in paragraphs 59 and following, stating that: "(...) in contrast to the situation of Uber's drivers, both hotels and airlines are undertakings which function completely independently of any intermediary platform and for which such platforms are simply one of a number of ways of marketing their services. Furthermore, it is the botels and airlines — and not the booking platforms — that determine the conditions under which their services are provided, starting with prices. (22) These undertakings also operate in accordance with the rules specific to their sector of activity, so that booking platforms do not exert any prior control over access to the activity, as Uber does with its drivers. 60. Lastly, such booking platforms give users a real choice between several providers whose offers differ on a number of important points from the users' perspective, such as flight and accommodation standards, flight times and hotel location. By contrast, with Uber, these aspects are standardized and determined by the platform, so that, as a general rule, the passenger will accept the service of the most quickly available driver'.
} 
means of tariff parity clauses. ${ }^{23 / 24}$

In my view, it is doubtful whether Airbnb should be considered indispensable and that it has a decisive influence on the providers of the services. In this light, Airbnb would be covered by the E-commerce Directive. It is, therefore, expected that the decision of the CJEU on the qualification of this platform will reflect this. ${ }^{25}$

\section{The regulation of collaborative platforms in the European Union}

The emergence of collaborative platforms has resulted in a kind of "spontaneous liberalization" in the European Union and in the Member States. ${ }^{26}$

One of the questions is whether they should be regulated by specific legislation - and in this case, whether this should be developed by the European Union or, subsidiarily, by the Member States - or, on a different way, only be submitted to the general regime applicable to all sectors of economic activity (e.g. the General Regulation on Data Protection). ${ }^{27}$

The signals given by the European Commission allow it to anticipate that it does not want to intervene directly in the sector regulation stricto sensu of some platforms collaboratively going instead to a strategy that some call "wait and see".

${ }^{23}$ On these clauses see Colangelo and Maggiolino, Uber and the challenges for antitrust, 183; Thibaud Vergé, "Are price parity clauses necessarily anticompetitive?," CPI Antitrust Chronicle (January 2018), https://www.competitionpolicyinternational.com/wp-content/uploads/2018/01/CPI-Verge.pdf; Ariel Ezrachi, "The Competitive Effects of Parity Clauses on Online Commerce," European Competition Journal, vol. 11, issue 2-3 (2015): 488-519; Pinar Akaman, "The competition law assessment of platform most favored customer clauses," Journal of Law and Economics, vol. 12, issue 4 (December 2016): 781-833; Margherita Colangelo, "Parity Clauses and Competition law in Digital Marketplaces: The Case of Online Hotel Booking," Journal of European Competition Law \& Practice, vol. 8, issue 1 (2017): 3-14 and Dennis W. Carlton and Ralph A. Winter, "Vertical Most - Favored - Nation Restraints and Credit Card No -Surcharge Rules," The Journal of Law and Economics, vol. 61, No. 2 (May, 2018): 215-251.

${ }^{24}$ In the opposite direction, considering the irrelevance of the tariff parity clauses, see the opinion of Advocate-General Maciej Szpunar presented on Elite Taxi/Uber, May 11, 2017, case C-434/15, ECLI:EU:C:2017:364, footnote 22: "The fact that some platforms conclude rate parity agreements with hotels, under which hotels agree to refrain from offering rates elsewhere which are lower than those offered on the platform in question, is immaterial. These agreements do not involve the setting of prices for the services by the platform, but a commitment concerning the rate-related treatment of different trading partners. All the same, the competition authorities of several Member States have questioned rate parity clauses, which led to the establishment of the European working group on online booking platforms, under the aegis of the Commission".

${ }^{25}$ The European Commission issued a press release on 16 July 2018 in which it drew Airbnb's attention to the need to respect European consumer law and to ensure transparency of prices, clarify conditions and suppress clauses allegedly illegal. The statement is available at http:/ / europa.eu/rapid/press-release_IP18-4453_en.htm. An application for a preliminary ruling concerning Airbnb Ireland is pending before the CJEU. See case C-390/18. In that case, the questions referred for a preliminary ruling are: (1) Do the services provided in France by Airbnb Ireland UC via an electronic platform operated from Ireland benefit from the freedom to provide services provided for in Article 3 of Directive 2000/31 of the European Parliament and of the Council of 8 June 2000? (2) The restrictive rules relating to the exercise of the profession of estate agent in France, laid down by Law 70-9 of 2 January 1970 on intermediaries relating to real estate transactions, Hoguet, are enforceable against Airbnb Ireland UC? On the application of the Uber test to Airbnb, see Busch, The sharing economy at the CJEU.

${ }^{26}$ Thus, see Damien Geradin, "Uber and the Rule of Law: Should Spontaneous Liberalization Be Applauded or Criticized?," Competition Policy International (2015); George Mason Law \& Economics Research Paper, No. 15-53 (November 2015), https:/ / ssrn.com/abstract=2693683.

${ }^{27}$ On the application of the General Regulation of Data Protection to the collaborative economy see Vassilis Hatzopoulos, The collaborative Economy and US Law (Bloomsbury: Hart Publishing, 2018), 67-102. 
This strategy can be understood in light of the principle of conferral powers on the one hand and the principle of subsidiarity on the other. There are activities for which the European Union has no powers - e.g. labour law ${ }^{28}$ or short-term lease - and in other cases, the principle of subsidiarity may require the Member States to exert regulatory jurisdiction, as explained by the CJEU in the case of Elite Taxi/Ubervis-a-vis the transport sector.

The neutrality followed by the European Commission makes it possible to move away from fracturing discussions around collaborative platforms, while ensuring de jure condito the essential legal regulation of collaborative platforms. ${ }^{29}$ This, sometimes, unclear strategy has already been criticized by the European Parliament. ${ }^{30}$

This strategy for collaborative platforms and its specific regulation can be also understood because many of the questions they raise can be addressed through existing legal instruments, such as competition law - as discussed below - or legislation such as the Services-Directive, the E-commerce-Directive ${ }^{31}$ the Payment Services Directive ${ }^{32}$ or the General Regulation on Data Protection. ${ }^{33}$

Recently, the European Commission seems to have distanced itself from the neutrality strategy referred to by submitting, in April 2018, a proposal for a Regulation on promoting fairness and transparency for business users of on-line brokering services $^{34}$. However, the proposal does not apply to collaborative platforms (like Uber and Airbnb) but only the "services of online intermediation". ${ }^{35}$

The European Commission has, therefore, sought to ensure a certain degree of neutrality in the legal analysis of collaborative platforms, distancing it from the epicenter

${ }^{28}$ As noted by the Advocate-General Maciej Szpunar in the conclusions presented in Elite Taxi/Uber, 11 May 2017, case C-434/15, EU:C:2017:364, note 19 he "not will discuss the legal relationship between Uber and its drivers, since that aspect is subject to national law".

${ }^{29}$ It is also understandable, therefore, that the European Commission has adopted soft law instruments - such as the communication "A European Agenda for Collaborative Economy" - through which it seeks to explain the application of existing legal instruments to electronic platforms or conducted several studies on collaborative economics such as the interesting one published in 2018 "Study to monitor the business and regulatory environment Affecting the collaborative economy in the EU", available at https://publications.europa.eu/en/publication-detail/-/publication/79bee7ad-6d22-11e89483-01aa75ed71a1/language-en/format-PDF/source-72448577

${ }^{30}$ See paragraph 15 of the report on a European Agenda for Collaborative Economy of 11 May 2017 (2017/2003 (INI)), available at http:/ /www.europarl.europa.eu/sides/getDoc.do?pubRef= - // $\mathrm{EP} / /$ TEXT + REPORT + 0 + DOC + A8-2017-0195 + XML + V0 // EN: “(...) regretted that the communication has not been sufficiently clear about the applicability of existing EU legislation to different models of collaborative economics". In this report, the European Parliament asked the European Commission for a "balanced, more comprehensive and ambitious strategy" for the European Union on the collaborative economy and presented a set of recommendations.

31 This Directive provides in Article 16 for self-regulatory forms which have been used by some platforms such as Amazon or Ebay. In this regard see Hatzopoulos, The collaborative, 14.

${ }^{32}$ Directive 2015/2366 of the European Parliament and of the Council of 25 November 2015 on payment services in the internal market.

${ }^{33}$ This Regulation is a corollary of the right to the protection of personal data concerning them, provided for in Article 8 of the European Charter of Fundamental Rights. See Regulation 679/2016 of the European Parliament and of the Council of 27 April 2016 on the protection of individuals with regard to the processing of personal data and on the free movement of such data.

${ }^{34}$ See Brussels, 26.4.2018, COM (2018) 238 final. The proposal was submitted under Article 114 TFEU, which aims to approximate the provisions of the Member States and ensure the application of non-discriminatory and coherent rules within the Union.

35 The proposal defines these services, in accordance with Article 2 (2), as those constituting information society services within the meaning of Article 1 (1) (b) of Directive 2015/1535 of the European Parliament and of the Council. 
of a debate which, for some platforms such as Uber or Airbnb, is still controversial in several Member States and where there is still an ongoing discussion regarding many of these activities. ${ }^{36}$ Many people support and encourage these platforms because of the benefits they bring to consumers in particular because of the prices and innovation that underlie them. ${ }^{37}$ Many others criticize them for, among other reasons, calling into question typical traditional business models (e.g. taxis); for contributing to speculation and removal of local populations in large urban centers (e.g. Airbnb) or even for being anti-democratic by qualifying platforms that aggregate data as, ironically, BAADD ("too big, anti-competitive, addictive and destructive to democracy")..$^{38}$

Specifically, in the case of taxis, licensing regulation was understood as a response to market failures ${ }^{39}$ ensuring quality. The practice of regulated prices, to the adjustment of ex ante demand, is a way to avoid congestion in cities and, in the end, to protect consumers. ${ }^{40}$ However, in the opposite way, many say that regulation only allowed the interests of incumbents to be safeguarded, generating an inability to increase competition. In this last dimension, the emergence of electronic platforms helped to enhance competition and the welfare of consumers and, doing so, raised the quality of the services provided and introduced better price adjustments and more innovative offerings. ${ }^{41}$

\footnotetext{
${ }^{36}$ On the democratic legitimacy of the European Union in times of economic crisis, Nuno Cunha Rodrigues, "Os novos muros da Europa," European Analysis, Journal of the Portuguese Association of European Studies, vol. II, No. 198-207 (May, 2017), http:/ /www.apeeuropeus.com/uploads/6/6/3/7/66379879/ european_analysis_2_3_2017.pdf.

${ }^{37}$ Conducting an economic analysis of the relationship between competition and innovation see Philippe Aghion, Stefan Bechtold, Lea Cassar and Holger Herz, "The Causal Effects of Competition on Innovation: Experimental Evidence," The Journal of Law, Economics and Organization, vol. 34, No. 2 (2018): 162-195.

${ }^{38}$ Thus, see Evan Smith, "The Techlash Against Amazon, Facebook, and Google-and What They Can Do," The Economist, January 20, 2018, https://www.economist.com/briefing/2018/01/20/thetechlash-against-amazon-facebookand-google-and-what-they-can-do.

${ }^{39}$ On the role of economic regulation as an instrument for correcting market failures see Nuno Cunha Rodrigues, "A regulação da saúde", in Regulação em Portugal, novos tempos, novo modelo? ed. Gonçalo Anastácio, Eduardo Paz Ferreira and Luís Silva Morais (Coimbra: Almedina, 2009), 613-651.

${ }^{40}$ Among the main arguments put forward by those who advocate maintaining taxis regulation is the need to avoid a lack of control to generate excessive taxis - with increased traffic congestion and pollution - and an increase competition between taxis likely to lead to a reduction in the quality of the service provided. The regulation will also ensure the adequacy of the prices charged to customers while safeguarding their safety. However, in the opposite direction, several authors point out that the regulation of taxis has failed, generating a shortage of supply, lack of incentives to reduce prices, an increase in quality and innovative solutions, and in some cases the capture of the regulator. On the regulation of taxis in Portugal see International Transport Forum, Regulation of For-Hire Passenger Transport. Portugal in International Comparison (Paris: ITF, 2016), https://www.itf-oecd.org/sites/default/files/docs/regulation-for-hire-passengerportugal.pdf. Carrying out the economic analysis of the regulation of taxis in Ireland, see Paul K. Gorecki, Evaluation of competitive impacts of government interventions, DAF/COMP/WP2(2014)6 (Paris: OECD, 2014), https://one.oecd.org/document/DAF/COMP/WP2(2014)6/en/pdf and Colangelo and Maggiolino, Uber and the challenges for antitrust, 179.

${ }^{41}$ Considering positive benefits from electronic transport platforms, see the report from the Portuguese Competition Authority (Autoridade da Concorrência), Relatório sobre Concorrência e Regulação no Transporte de Passageiros em Veículos Ligeiros, dezembro de 2016, available at http://www. concorrencia.pt/vPT/Noticias_Eventos/ConsultasPublicas/Documents/Relat $\%$ C3\%B3rio $\% 20$ sobre $\% 20$ Concorr $\%$ C3 $\%$ AAncia $\% 20$ e $\% 20$ Regula $\%$ C 3 $\%$ A $7 \%$ C $3 \%$ A3o $\% 20$ no $\% 20$ Transporte $\% 20$ de $\% 20$ Passageiros $\% 20 \mathrm{em} \% 20 \mathrm{Ve} \% \mathrm{C} 3 \%$ ADculos $\% 20$ Ligeiros.pdf, paragraph 165 and following (written in Portuguese). These benefits include reducing transaction costs; coordination and the creation of supply side efficiencies (density savings); the mitigation of asymmetries of information
} 


\section{The application of competition law to collaborative platforms}

The search for legal responses to collaborative platforms has found in the plasticity of competition law fertile ground for discussion and mitigation of some of the difficulties they may pose, as was already recognized by the CJEU. ${ }^{42}$ Still, the truth is that the application of this branch of law to collaborative platforms demands answers to previous questions.

Firstly, it is important to determine whether collaborative platforms are considered to be undertakings according to competition law. ${ }^{43}$

One should recall that the concept of undertaking for the purposes of competition law has been built from the praetorian construction of the CJEU under which neither the legal personality, the legal status, financing arrangements or non-profit making are decisive for the definition. The decisive element is the pursuit of an economic activity - which is considered to be the supply of goods or services on a relevant market autonomously, which can be carried out by a private profitable enterprise (even if that economic activity is, at the end, specifically carried out by a non-profit entity).

In the case of electronic platforms, it will be necessary to check whether they exercise an economic activity autonomously ${ }^{44}$ which seems to occur if the Uber test conditions are met. ${ }^{45}$ In situations where this does not happen - verbi gratia if the platform ensures P2P commerce model or is considered as a provider of information society services - the question remains of the application to electronic platforms of the concept of undertaking for the purposes of competition law to the extent that there is, strictly speaking, supply of goods and services on a given market but the platforms only exercise a mere activity of intermediation (not having control over the services provided). ${ }^{46}$

If collaborative platforms are to be considered as undertakings for the purposes of competition law, one will have to deal with a second issue: the determination of the relevant market(s) in which they act. ${ }^{47}$ For example, in the recent past Uber argued that,

since they provide information to the consumer and reduce the context of uncertainty in which it makes its decision, namely regarding the conditions of the services that will be provided (price, waiting time, quality); the different segments of taxi services (hailing, taxi stands and pre-contracted services). With regard to the benefits of platforms, see also Einav, Farronato and Levin, Peer-to-Peer Markets, 627-629.

${ }^{42}$ Thus, see the Opinion of the Advocate-General Maciej Szpunar presented on Elite Taxi/Uber,11 May 2017, case C-434/15, ECLI:EU:C:2017:364, paragraph 62: “(...) consider Uber a platform independent service providers could raise issues from the point of view of competition law. However, I shall not elaborate on this point more broadly, since it goes beyond the scope of this case".

${ }^{43}$ On the concept of undertaking according to competition law, see Nuno Cunha Rodrigues, $A$ contratação pública como instrumento de política económica (Coimbra: Almedina, 2013), 381-386. See also, in the Portuguese Competition Law, Article 3 (1) of Law No. 19/2012, of $8^{\text {th }}$ May.

${ }^{44}$ On the independent action of an operator on the market, see Judgment Eturas, 21 January 2016, case C-74/14, ECLI:EU:C:2016:42, paragraph 27 and the case-law cited therein.

${ }^{45}$ In the specific case of Uber, it may also be questioned whether the concept of an undertaking covers the underlying service providers - the drivers acting in favor of Uber - given the existing economic unit. In Italy, the courts have observed that Uber can not be considered disconnected from the drivers who provide the service since they are not free to negotiate the price with passengers and are obliged to apply tariffs calculated by an algorithm that raises prices when demand is increased. Thus, see Amato, Uber and the Sharing Economy, 178.

${ }^{46}$ Notwithstanding, this too can be regarded as an economic activity and be defined as the relevant product market.

${ }^{47}$ The relevant theoretical market concept must take into account the Commission notice on the definition of the relevant market, even though it does not necessarily have to be followed by the 
in India, it was part of the product relevant market of "radio taxi services in Delhi”. In New York, as part of a complaint filed against the CEO of Uber, it discussed whether the relevant product market for Uber was the "applications for car-sharing services" 48 or whether, on the opposite, it included "taxis, public transport and pedestrian routes". 49

In my view, this exercise is speculative vis-a-vis the novelty of the platforms and the (lack) of decision-making practice of competition authorities around the world which is not yet sufficiently stabilized in order to allow it to consider the relevant markets in which electronic platforms such as Uber or Airbnb intervene.

There are, however, on-going investigations and decisions handed down by various competition regulators worldwide that legitimize the anticipation of judgments on the possible application of competition rules (if one considers the qualification of the collaborative platform as undertakings and the consequent relevant market is defined). ${ }^{50}$

If that happens, competition law can be applicable to electronic platforms and the assessment of possible anti-competitive practices such as hub and spoke $\mathrm{e}^{51}$ - where the collaborative platform would be considered as the hub -, the shared use of algorithms between platforms (likely to be qualified as an agreement between undertakings) ${ }^{52} \mathrm{can}$ occur [Article 101 (1) TFEU].

national competition authorities or the courts. See Commission Notice on the definition of relevant market for the purposes of Community competition law, OJEC No. C 372, (December 1997): 3.

48 The original definition corresponds to the market "mobile app-generated ride-share service market". See the preliminary ruling available at https://cases.justia.com/federal/district-courts/new-york/ nysdce/1:2015cv09796/451250/37/0.pdf?ts=1459545536. In this regard, see Parveer S Ghuman, "Analysis of Competition Cases Against Uber Across the Globe," Working Paper CUTS International (March 2017): 6, http://www.cuts-ccier.org/pdf/Analysis_of_Competition_Cases_Against_Uber_ Across_the_Globe.pdf

${ }^{49}$ In this regard, see Ghuman, Analysis of Competition Cases Against Uber, 6.

${ }^{50}$ We limit ourselves to examining such practices in the light of European Competition law, knowing that the national application of Competition law follows the same line of reasoning.

${ }^{51}$ In a bub and spoke practice the agreement or concerted practice carried out between competing undertakings (spoke) is done indirectly through a third company (hub) which can act on the same market or even in a totally different market. In this regard see Judgment AC-Treuhand, 22 October 2015, case C-194/14 P, ECLI:EU:C:2015:717, paragraph 36 where it is recognized that Article 101 (1) allows to react against the active contribution of a company to a restriction of competition even if that contribution is not part of an activity which is included on the relevant market in which this restriction materializes or is intended to materialize. See also the Opinion of Advocate General Maciej Szpunar presented on Elite Taxi/Uber, 11 May 2017, case C-434/15, ECLI:EU:C:2017:364, footnote 23 where it states that "the use by competitors of the same algorithm to calculate the price is not in itself unlawful, but might give rise to hub-and-spoke conspiracy concerns when the power of the platform increases" and Ariel Ezrachi and M. E. Stucke, "Artificial Intelligence \& Collusion: When Computers Inhibit Competition", CCLP Working Paper 40 (2015), 14.

${ }^{52}$ See Article 101 (1) TFEU. On the distinction between agreements between undertakings and concerted practice, see Judgment AC-Treuhand, 22 October 2015, case C-194/14 P, ECLI:EU:C:2015:717, in particular paragraphs 28; 29 and 32. On the anti-competitive effect of the algorithms see Ai Deng, "What Do We Know About Algorithmic Tacit Collusion?," Antitrust Magazine No. 33, 1 (2018): 88-95 and Anita Banicevic, Gabrielle Z. A. Kohlmeier, Dajena Pechersky and Ashley Howlett, "Algorithms: challenges and opportunities for antitrust compliance," ABA-SAL Compliance and Etbics Committee Spotlight, Special Report: Antitrust Law (Fall 2018). On the application of competition law in the context of the big data, see Eliana Garcés, "Data collection in online business platforms: a perspective for antitrust assessment," CPI Antitrust Chronicle: Diving into online platforms, vol. 2 (Spring 2018): 17 25, https://www.competitionpolicyinternational.com/wp-content/uploads/2018/05/AC_May.pdf and Tánia Luísa Faria, "Direito da concorrência e big data: ponto da situação e perspectivas,” Revista Concorrência e Regulação ano VIII, n. ${ }^{\circ} 29$ (Jan/2017-Mar/2017): 107-137. 
Also practices of predatory pricing; ${ }^{53}$ holding of data by the same company ${ }^{54}$ or the imposition, by a collaborative platform, of tied or bundle sales (as practices of abuse of dominant position) ${ }^{55}$ can be scrutinized (Article 102 TFEU). ${ }^{56}$

Still, one should take into account that any anti-competitive collective practices involving collaborative platforms [Article 101 (1) TFEU] can be justified in accordance with Article 101 (3) TFEU. Knowing the decisive role that the collaborative platforms play in innovation and the pro-competitive benefit that results from it, ${ }^{57}$ it is legitimate to recognize that, in some situations, practices pursued by collaborative platforms, sanctioned in light of Article 101 (1) TFEU, can be justified under the conditions set out in Article 101 (3) TFEU.

In short, competition law can provide answers to new questions arising from collaborative platforms but does not, per se, solve all the problems posed by these, ${ }^{58}$ since it has a general ex-post application vocation ${ }^{59}$ (without prejudice to the proper field of application of regulation on the control of concentrations between undertakings). ${ }^{60}$

\section{Conclusions}

The emergence of collaborative platforms poses new challenges for the European Union and the Member States.

The CJEU contributed, with the Elite Taxi/Ubercase, to establish some semblance of clarity in the legal regime applicable to collaborative platforms, by defining a test that will surely be applied in the future to other forms of collaborative economy.

Nevertheless, the European Commission has followed a neutral strategy ("wait

\footnotetext{
${ }^{53}$ On Uber's practice of predatory pricing in the United States see Nick Passaro, "Uber has an antitrust litigation problem, not an antitrust problem," CPI Antitrust Chronicle: Diving into online platforms, vol. 2 (Spring 2018): 38-32, https://www.competitionpolicyinternational.com/wp-content/ uploads/2018/05/AC_May.pdf.

${ }^{54}$ In this regard see Maurice E. Stucke, "Should we be concerned about data- opolis?," Georgetown Law Technology Review, University of Tennessee Legal Studies Research Paper, n. 349 (2018): 275-324, https:/ / ssrn. com $/$ abstract $=3144045$.

${ }^{55}$ In this regard see Hatzopoulos, The collaborative, 141.

${ }^{56}$ There are also known complaints by Uber against taxi drivers for abusive litigation (sham litigation). In July 2018 CADE, in Brazil, filed a complaint by Uber against taxi drivers, available at http://www.cade. goseebr/noticias/cade-arquiva-investigacao-no-applicadora-de-aplicativo-de-transport-individual-ofpassengers.

${ }^{57}$ On the disruptive effect of collaborative platforms on competition law see Riccardo Falconi, "Uber: Has digital economy disrupted competition law?," Revista Concurrences, n. ${ }^{\circ} 3-2018$, article n. ${ }^{\circ}$ 87312 (September 2018).

${ }^{58}$ Noting that the core problems that Uber and Airbnb face lie in the lack of regulation; absence of fiscal framework and deregulation that they place in labor terms, see Selloni, Codesign for public-interest services, 21-26.

${ }^{59}$ In other words, the intervention of competition law arises as a result of the undertakings actions in the markets. As Colangelo and Maggiolino, Uber and the challenges for antitrust, 187 noticed, “(...) anti-trust enforcers have limited powers. They can only forbid anticompetitive agreements, mergers and monopolistic practices. They can not prescribe obligations and commitments to impose, for example, Uber to comply with taxi regulations".

${ }^{60}$ In this regard see Ben Holles de Peyer, "US merger control and big data," Journal of Competition law \& Economics, vol. 13, issue 4, (December 2017): 767-790. In Singapore, Uber was fined \$ 13 million in September 2018 because, as a result of the acquisition of its subsidiary in Singapore by Grab (a local company competing with Uber), Grab had obtained a market share of $80 \%$. Nevertheless, the acquisition was not reversed and remedies were set out by the National Competition Authority (Competition and Consumer Commission of Singapore). For more information see https://www. tnp.sg/news/singapore/grab-Uber-fined-13-million-breaking-competition-laws.
} 
and see") for collaborative platforms that does not allow the required clarification of the regulatory model applicable. ${ }^{61}$

The debate around the regulation of collaborative platforms - such as Uber or Airbnb - remains open. ${ }^{62}$

In the absence of a response from the European Union, some Member States have regulated some of the collaborative platforms, as in Portugal with respect to $U_{b e r}{ }^{63}$ and possibly Airbnb. ${ }^{64}$

These forms of regulation emerge at a national level, ${ }^{65}$ to the detriment of a

\begin{abstract}
${ }^{61}$ Many authors point out that there is a lack of definition regarding an ex-ante or ex-post model of regulation namely concerning the definition of a model (a) ex-ante or ex-post; (b) bottom-up or topdown or collaborative; (c) local; national or supranational or (d) transversal or sectorial. See Hatzopoulos, The collaborative, 217-220.
\end{abstract}

${ }^{62}$ Some Member States have chosen to ban part of the services provided by Uber. Uberpop platform was banned in Member States such as France; Italy and Germany. Uberblack was banned in Italy but readmitted later in May 2017 following a decision of the Court of Rome. Reporting several court cases in Europe, see Amato, Uber and the Sharing Economy, 177-183 and Colangelo and Maggiolino, Uber and the challenges for antitrust, 179. See the opinion of Advocate-General Maciej Szpunar, presented on Elite Taxi/Uber, 11 May 2017, case C-434/15, ECLI:EU:C:2017:364, footnote 12 where some court decisions of Member States are listed as to the manner in which Uber operates, such as the judgment of the London Employment Tribunal of 28 October 2016, Aslam, Farrar and Others see Uber (case 2202551/2015); decision of the Audiencia Provincial de Madrid n 15/2017, dated January 23, 2017, in the lawsuit filed by Uber against the Asociación Madrileña del Taxi, and order of the Tribunale Ordinario di Milano of July 2, 2015 (cases 35445/2015 and 36491/2015).

${ }^{63}$ The Portuguese Competition Authority (Autoridade da Concorrência) presented, in December 2016, a Report on Competition and Regulation on the Transport of Passengers in Vebicles (Relatório sobre Concorrência e Regulação no Transporte de Passageiros em Veículos Ligeiros), available at http:// www.concorrencia.pt/vPT/Noticias_Eventos/ConsultasPublicas/Documents/Relat $\% C 3 \%$ B3rio\%20 sobre $\% 20$ Concorr $\%$ C3\%AAncia $\% 20$ e $\% 20$ Regula $\%$ C3\%A7\%C3\%A3o\%20no $\% 20$ Transporte $\% 20$ de $\% 20$ Passageiros $\% 20 \mathrm{em} \% 20 \mathrm{Ve} \% \mathrm{C} 3 \% \mathrm{AD}$ culos $\% 20$ Ligeiros.pdf. In this report, AdC criticizes the model in force in Portugal for the provision of taxi services because it considers that "(...) regulatory tariffs eliminate price as a variable of competition and limit the incentives of operators to compete in the binomial quality / price (...)" which could "(...) imply losses of welfare" (see p.1). This is why the AC understood that the legislation then in force which established provisions regarding (i) Regulation at the level of entry into the market; (ii) Regulation of price of services and (iii) Regulation of quality / safety and other aspects of the exercise of the activity should be changed. Later, in 2018, in Portugal, the so-called "Uber Law" - Law n. ${ }^{\circ} 45 / 2018$, of August 10 - was approved. It regulates the transportation in a deprived vehicle that provides services to an electronic platform (TVDE). It should be noted, however, that in accordance with article 1, paragraph 2, this law does not apply to: (A) Electronic platforms that are only aggregators of services and do not define the terms and conditions of a business model own (B) vehicles sharing activities without profit (carpooling) and vehicle rental without a short conductor with sharing features (carsharing), organized or not by platform electronic. In other words, the law only applies to collaborative platforms that pass the "Uber test", with the remaining ones - including those that do not pass the test or that act in the context of the sharing economy (P2P) - outside the scope of that law.

${ }^{64}$ Some municipalities in Portugal have considered the application of limits to the provision of local accommodation, thus conditioning the activity pursued by collaborative platforms such as Airbnb.

${ }^{65}$ As the Portuguese Competition Authority notes in the Report on Competition and Regulation on the Transport of Passengers in Vehicles, p. 46, the regulatory framework must respect three pillars of efficient regulation: (i) necessity, (ii) proportionality, and (iii) non-discrimination. The International Transport Forum, in the 2016 document entitled App-based ride and taxi services: Principles for regulation, p. 30 (available at https://www.itf-oecd.org/sites/default/files/docs/app-ride-taxi-regulation.pdf) proposes ten principles for regulation which should (i) be limited to correcting market failures; (ii) rely on the most efficient tools; (iii) be technologically neutral and non-discriminatory between operators; (iv) allow for regular impact assessment; (v) ensure the sharing of regulatory responsibilities; (vi) be clear and easily understandable; (vii) be adaptable; (viii) be objective; (ix) be based on fundamental economic principles and (x) be inclusive of all social groups. 
European approach which would lead to greater harmonization at the European level and to the affirmation of a level playing field within the Internal Market, although it could produce misunderstandings among populations in the face of the divergence of opinion that persists in many Member States.

For all these reasons, it is expected that the European Commission's strategy will continue favoring the issuance of soft law instruments and the ability of the actual legal framework of EU law to provide answers to some of the legal challenges posed by collaborative platforms.

It is certain that the arrival of collaborative platforms, regardless of future developments that may have led to the modification of behavior in often less dynamic and innovative sectors - given the fact that many are incumbents - provoked what some refer to an electric shock in many industries, which led to an increase in the quality and efficiency of several services previously provided without competition, thus broadening the well-being of consumers. ${ }^{66}$ The legal classification of these services is, therefore, essential for determining the regulatory framework applicable to the collaborative economy nowadays.

\footnotetext{
${ }^{66}$ Thus, see Geradin, Uber and the Rule of Law and Colangelo and Maggiolino, Uber and the challenges for antitrust, 188: "(...) the best way to fight illegal business models is to develop legal business models that are equally good and efficient. After all, this is what the piracy teaches us about".
} 